\title{
Personnel Information System Using Microsoft Excel (Case Study: Bima City Health Office)
}

\section{Sistem Informasi Kepegawaian Dengan Menggunakan Microsoft Excel (Studi Kasus: Dinas Kesehatan Kota Bima)}

\author{
$1^{\text {st }}$ Wulan Ramdhani ${ }^{1}, 2^{\text {nd }}$ Arizona Firdonsyah ${ }^{2}$ \\ \{wulanramdhani047@gmail.com, ${ }^{1}$, arizona@unisayogya.ac.id ${ }^{2}$ \}
}

Program Studi Teknologi Informasi, Fakultas Sains dan Teknologi Universitas 'Aisyiyah Yogyakarta, Jl. Siliwangi (Ring Road Barat) No.63, Yogyakarta, Indonesia ${ }^{1,2}$

\begin{abstract}
Information system is a system that has the ability to collect information from all sources and use various media to display information. Microsoft Excel is a spreasheet application program (electronic worksheet), the function of Microsoft Excel is to perform calculation operations and can present data in table form, while the filter and sort data functions are used to sort or filter data, for example: the ascending function and descending to sort data from the largest or from the smallest, the Sort By and Sort On features, in addition to the filter function to display data with certain criteria, the filter feature function or often referred to as autofilter, which functions to display certain rows of data according to filters already applied and hides the rest of the remaining rows of data. This study aims to facilitate the search for staffing data at the Health Office of the City of Bima, the method of data collection using 2 methods, namely literature study and observation, the results of research that have been conducted are that there is no personnel information system because the process of searching and recording personnel data is still done manually.
\end{abstract}

Keywords - Information Systems; Staffing; Microsoft Excel

\begin{abstract}
Abstrak - Sistem informasi merupakan suatu sistem yang mempunyai kemampuan untuk mengumpulkan informasi dari semua sumber dan menggunakan berbagai media untuk menampilkan informasi. Microsoft Excel merupakan program aplikasi spreasheet (lembar kerja elektronik), fungsi dari Microsoft Excel adalah untuk melakukan operasi perhitungan serta dapat mempresentasikan data ke dalam bentuk tabel, sedangkan fungsi filter dan sortir data yaitu yang digunakan untuk mensortir maupun menyaring data, contohnya: fungsi ascending dan descending untuk mengurutkan data dari yang paling besar atau dari yang paling kecil, fitur Sort By dan Sort On, selain itu juga fungsi filter untuk menampilkan data dengan kriterie tertentu, fungsi fitur filter atau sering disebut juga sebagai autofilter yaitu berfungsi untuk menampilkan baris data tertentu sesuai filter yang sudah diterapkan dan menyembunyikan sisa baris data yang lain. Penelitian ini bertujuan untuk mempermudah pencarian data kepegawaian di Dinas Kesehatan Kota Bima, metode pengumpulan data menggunakan 2 metode yaitu studi pustaka dan observasi, hasil penelitian yang telah dilakukan bahwa belum adanya sistem informasi kepegawaian karena dalam proses pencarian dan pencatatan data kepegawaian masih dilakukan secara manual.
\end{abstract}

Kata Kunci - Sistem Informasi; Kepegawaian; Microsoft Excel

\section{Pendahuluan}

Teknologi informasi dan teknologi komputer pada saat ini berkembang dengan pesat, kebutuhan tersebut semakin diminati oleh semua kalangan masyarakat, baik masyarakat awam maupun kaum intelektual, hal ini berkaitan dengan kegiatan-kegiatan yang sering dilakukan manusia yang biasanya dilakukan secara manual dan tradisional, kini akan semakin lebih cepat dan tepat jika dilakukan dengan bantuan mesin yaitu teknologi komputer, kemajuan teknologi informasi dan teknologi komputer tersebut mengakibatkan semakin berkembangnya pemahaman manusia tentang pentingnya aspek teknologi dalam suatu perusahaan, instansi, atau organisasi, sehingga pada masa sekarang ini teknologi informasi juga telah banyak digunakan oleh perusahaan, lembaga pendidikan maupun organisasi untuk media publikasi.[1]

Sistem Informasi Kepegawaian (SIMPEG) adalah sistem yang mampu memberikan informasi datadata pegawai pada suatu perusahaan maupun instansi yang saling berinteraksi mencapai tujuan yang telah ditargetkan. SIMPEG menangani pengelolaan data kepegawaian khususnya meliputi: pendataan pegawai, BKD, proses perencanaan dan formasi kepegawaian, penggajian, penilaian angka kredit, mutasi pegawai, dan sistem pelaporan.[2]

Pegawai merupakan subjek penting dalam sebuah organisasi. Manusia memiliki kemampuan untuk menggerakkan semua sumber data organisasi yang ada, tanpa adanya pegawai yang baik, organisasi akan sulit 
berkembang karena kekuatan setiap organisasi terletak pada pegawai yang mengelola dan menanganinya, apabila pegawai diperhatikan secara tepat dengan menghargai bakat-bakat, mengembangkan kemampuan, dan menggunakannya secara tepat maka organisasi akan menjadi dinamis dan berkembang.[3]

Undang-Undang Nomor 43 Tahun 1999 tentang perubahan Undang-undang Nomor 8 Tahun 1974 tentang Pokok-Pokok kepegawaian, bahwa yang di maksud dengan pegawai adalah warga negara Republik Indonesia yang memenuhi syarat-syarat yang di tentukan dalam peraturan perundang-undangan yang berlaku, diangkat oleh pejabat yang berwenang dan diserahi tugas negara dalam suatu jabatan serta digaji menurut peraturan perundang- undangan yang berlaku.[4]

Sistem informasi merupakan suatu sistem yang mempunyai kemampuan untuk mengumpulkan informasi dari semua sumber dan menggunakan berbagai media untuk menampilkan informasi[5]. Sistem Informasi dapat didefinisikan sebagai kombinasi dari individu, hardware, software, jaringan telekomunikasi, data, dan prosedur kebijakan yang digunakan untuk menyimpan dan menerima data yang kemudian ditransformasikan menjadi informasi dalam sebuah organisasi.[6]

Microsoft Excel merupakan program aplikasi spreasheet (lembar kerja elektronik), fungsi dari Microsoft Excel adalah untuk melakukan operasi perhitungan serta dapat mempresentasikan data ke dalam bentuk tabel, sedangkan fungsi filter dan sortir data yaitu yang digunakan untuk mensortir maupun menyaring data, contohnya: fungsi ascending dan descending untuk mengurutkan data dari yang paling besar atau dari yang paling kecil, fitur Sort By dan Sort On, dan fungsi filter untuk menampilkan data dengan kriterie tertentu, fungsi fitur filter atau sering disebut juga sebagai autofilter yaitu berfungsi untuk menampilkan baris data tertentu sesuai filter yang di terapkan dan menyembunyikan sisa baris data lainnya.[7]

Dinas Kesehatan Kota Bima dibentuk pertama kali melalui Surat Keputusan Wali kota Nomor 7 Tahun 2002 Tanggal 16 Agustus 2002, selanjutnya Dinas Kesehatan Kota Bima diatur melalui Peraturan Daerah Nomor 5 Tahun 2003, sejak terbentuknya Dinas Kesehatan tidak pernah mengalami perubahan Nomenklatur, selanjutnya ada tahun 2016 Dinas Kesehatan dibentuk berdasarkan Peraturan Daerah Kota Bima Nomor 5 Tahun 2016 tentang Pembentukan dan Susunan Perangkat Daerah Kota Bima, dengan Dinas Tipe B, adapun pengaturan mengenai struktur organisasi dan tugas pokok dan fungsi tertuang dalam Peraturan Walikota Nomor 41 Tahun 2016 tentang Kedudukan, Susunan Organisasi, Tugas dan Fungsi Serta Tata Kerja Dinas Kesehatan.[8]

Dinas Kesehatan Kota Bima sangat berperan penting dalam kemajuan sektor lembaga kesehatan, kondisi sistem informasi di Dinas Kesehatan Kota Bima yang masih minim, sehingga Dinas Kesehatan Kota Bima membutuhkan Sistem Informasi untuk membantu para manajer dan karyawan dalam bekerja terutama pada departemen kepegawaian yang memiliki peranan penting dalam pencatatan dan pelaporan nama-nama seluruh pegawai pada lingkup Dinas Kesehatan yang masih di lakukan secara manual, sehingga perlu adanya suatu sistem untuk mempermudah bagian departemen kepegawaian dalam mencari data dan identitas seluruh pegawai yang berada di lingkup Dinas Kesehatan Kota Bima, maka tujuan dari pembuatan sistem ini adalah untuk mempermudah pencarian data pegawai yang ada di Dinas Kesehatan Kota Bima yang masih di lakukan pencarian dan pencatatan data pegawai secara manual.

\section{METODE}

\section{A. Metode Pengumpulan Data}

Metode yang digunakan dalam pengumpulan data yaitu menggunakan 2 metode;

1. Studi pustaka yaitu mencari artikel serta referensi lain yang berkaitan dengan pembuatan sistem informasi kepegawaian dengan menggunakan microsoft excel. Studi pustaka atau kepustakaan dapat diartikan sebagai serangkaian kegiatan yang berkenaan dengan metode pengumpulan data pustaka, membaca dan mencatat serta mengolah bahan penelitian, berdasarkan dengan hal tersebut, maka pengumpulan data dalam penelitian dilakukan dengan menelaah atau mengekplorasi beberapa Jurnal, buku, dan dokumen-dokumen (baik yang berbentuk cetak maupun elektronik) serta sumber-sumber data dan informasi lainnya yang dianggap relevan dengan penelitian atau kajian. [9]

2. Observasi mengumpulkan data dengan cara pengamatan langsung terhadap semua kebutuhan yang diperlukan pada pembuatan sistem. Observasi adalah proses yang kompleks, suatu proses yang tersusun dari berbagai proses biologis dan psikologis, dua diantara yang wawancara berkaitan dengan bentuk pesan verbal dan non verbal dan juga hambatan hambatan yang ditemui oleh peneliti.[10]

\section{B. Metode Proses Pengolahan Data}

Metode proses pengolahan data yang dilakukan:

a. Proses Input data

Proses input data adalah kegiatan memasukan data kemudian diproses oleh sistem, pada proses ini yaitu memasukkan semua data pegawai yang sudah di kumpulkan lalu di masukkan kedalam sistem yang teah di buat. 
b. Proses pengolahan data

Proses pengolahan data yaitu kegiatan sistem mengelola data menjadi informasi, pada proses ini semua data yang di input akan di proses menjadi sebuah informasi mengenai data pegawai

c. Proses output data

Proses output data yaitu dari hasil informasi input dan proses pengolahan data, selanjutnya akan di proses oleh sistem.

\section{Hasil dan Pembahasan}

\section{Sistem yang dikerjakan menghasilkan:}

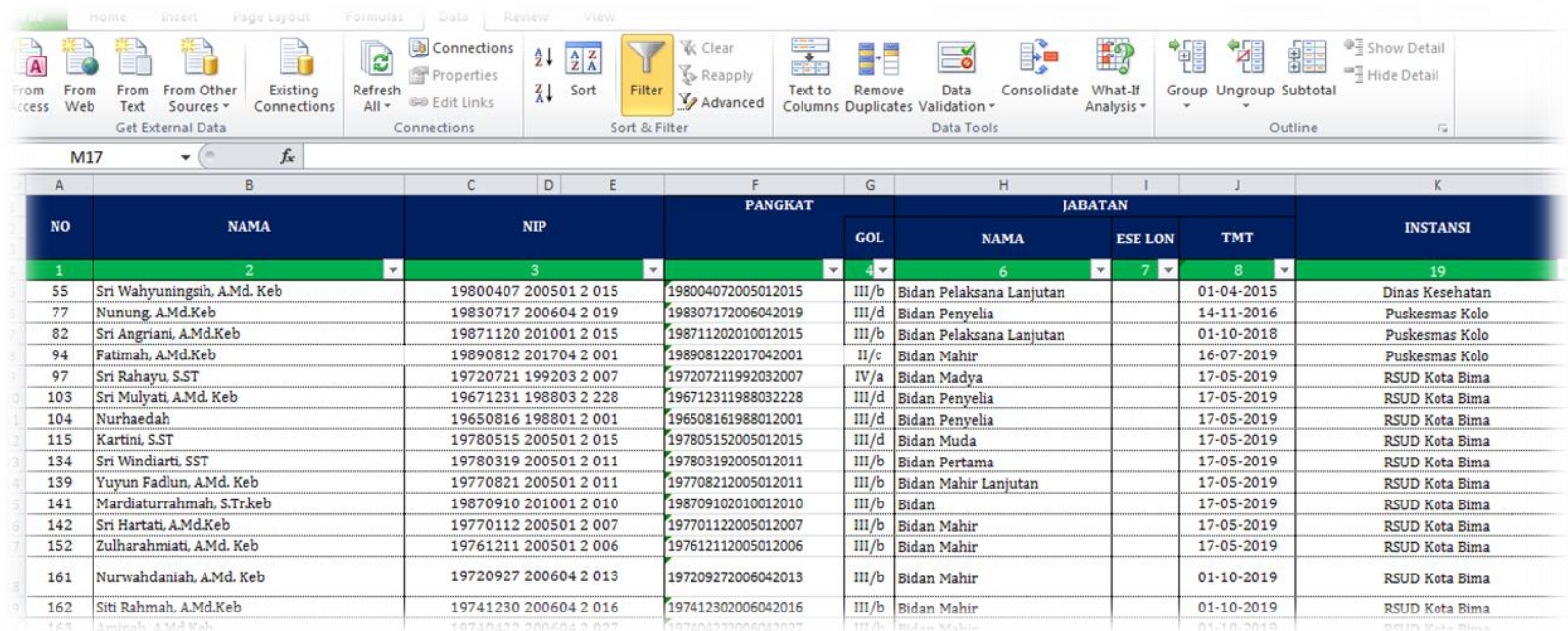

\section{Gambar 1 Tampilan Awal Sistem}

Gambar 1 menampilkan tampilan awal dari sistem yang berisikan no, nama pegawai, nip pegawai, pangkat, golongan, ese lon, tmt dan instansi, dari gambar sistem diatas fitur filter yang ada di microsoft excel sudah diaktifkan yang dimana ketika ingin menampilkan salah satu data pegawai maka dilakukan dengan cara klik lambang drop down.

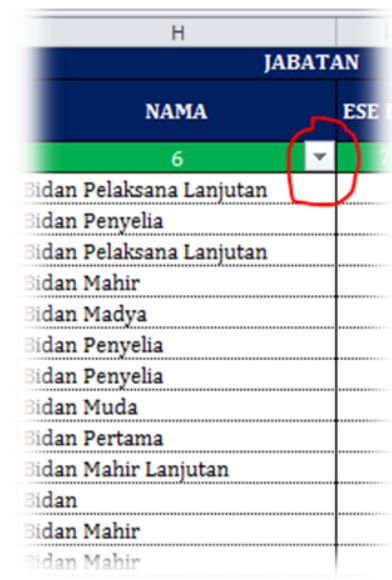

\section{Gambar 2 Kolom Nama Jabatan}

Gambar 2 menampilkan data jabatan pegawai dimana data jabatan tersebut belum diurutkan sesuai dengan abjad sehingga ketika ingin mencari data pegawai yang spesifik harus mencari satu-satu, tetapi dengan adanya fitur filter maka masalah tersebut bisa diatasi misalnya disini saya akan menerapkan fitu filter untuk kolom "NAMA JABATAN" dengan cara mengklik menu drop down pada header. 
Procedia of Engineering and Life Science Vol. 1. No. 2 Juni 2021

Seminar Nasional \& Call Paper Fakultas Sains dan Teknologi (SENASAINS 2nd)

Universitas Muhammadiyah Sidoarjo

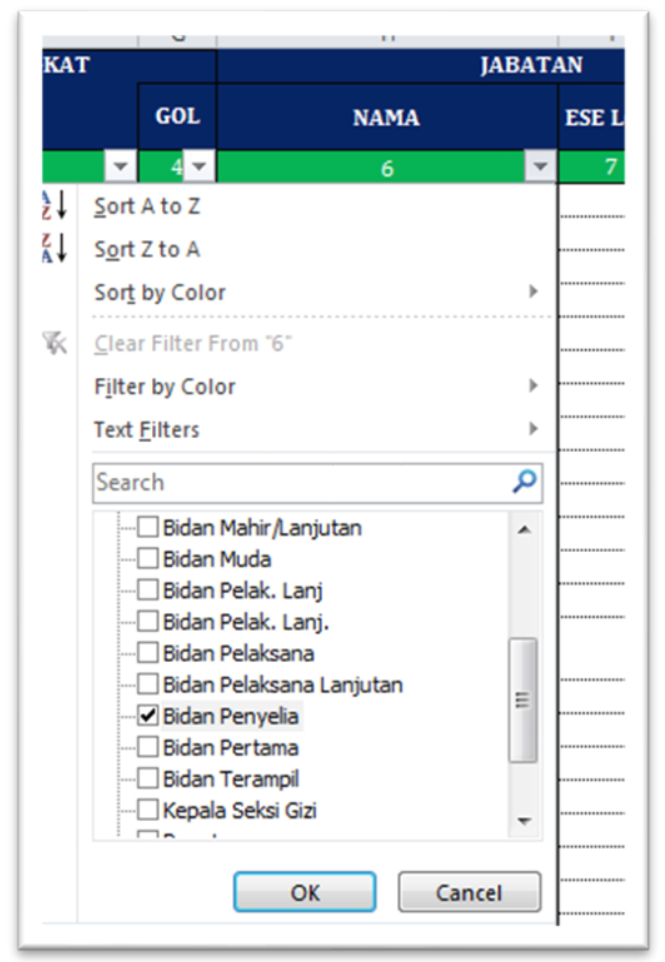

Gambar 3 Drop Down Kolom NAMA JABATAN

Gambar 3 menampilkan hasil dari menu drop down yang dipilih, contohnya disini saya memilih salah satu data yang ingin di tampilkan di "NAMA JABATAN" yaitu menampilkan data dari "Bidan Penyelia" cara menampilkannya dengan cara select data jabatan pegawai yang nama jabatannya adalah bidan penyelia kemudian klik ok maka otomatis hasil dari semua data pegawai yang jabatannya bidan penyelia akan muncul, bisa dilihat di gambar 4.

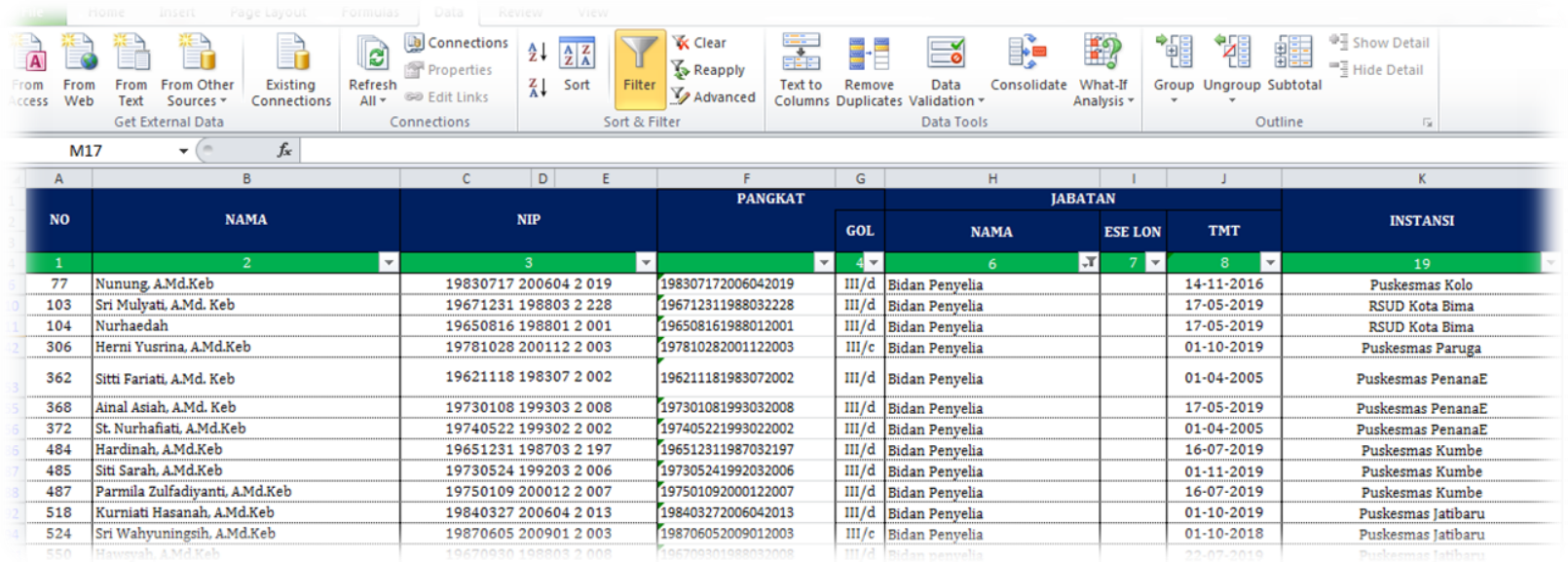

\section{Gambar 4 Hasil Filter Data Bidan Penyelia}

Gambar 4 menampilkan hasil filter data bidan penyelia yang berisikan nama, nip, pangkat, golongan, jabatan, tmt dan instansi, Jadi ketika ingin menampilkan salah satu data pegawai dari sistem ini maka akan muncul semua data pegawai yang spesifik dengan data yang di minta, oleh karena itu dengan adanya sistem ini dapat mempermudah dalam pencarian data yang diinginkan, yang awalnya data yang di cari dengan cara yang manual, tetapi setelah menggunakan fitur filter yang ada Microsoft Excel dapat mempermudah dalam pencarian data dan tidak memakan waktu cukup lama.

\section{A. Alur Pembuatan Sistem}

Kepegawaian Dinas Kesehatan Kota Bima memberikan tugas untuk membuat sebuah sistem dari microsoft excel yang isi dari sistem tersebut meliputi data- data pegawai, selain itu juga dinas kesehatan 
menginginkan dari sistem tersebut ketika mlakukan pencarian dan pencatatan data pegawai mudah dan cepat dilakukan, kemudian muncul ide untuk menggunakan fitur filter yang tersedia di microsoft excel, dengan begitu ketika melakukan pencarian data mudah dilakukan karena fitur filter ini berfungsi untuk menampilkan baris data tertentu sesuai filter yang di terapkan dan menyembunyikan sisa baris data lainnya.

Proses yang dilakukan ketika pembuatan sistem.

1. Mulai

2. Mengumpulkan data pegawai

3. Membuka microsoft excel

4. Membuat tabel sesuai dengan kebutuhan data pegawai

5. Memasukkan data pegawai di tabel yang sudah dibuat

6. Jika datanya tidak sesuai maka lakukan pengecekan ulang pada data, jika datanya sesuai maka langsung ke langkah 5

7. Mengakifkan fitur filter dari tabel data pegawai

8. Mengimplentasi sistem.

9. Selesai

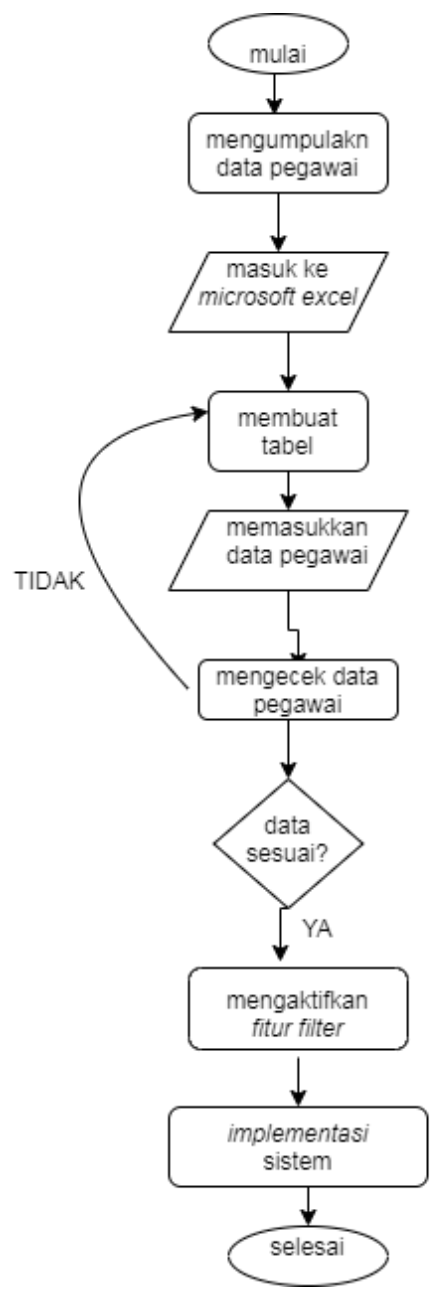

Gambar 5 Flowchart alur pembuatan sistem

Gambar 5 menjelaskan flowchart alur pembuatan sistem yaitu yang pertama dilakukan adalah mengumpulkan data pegawai setelah data terkumpul selanjutnya membuka microsoft excel, kemudian setelah mengumpulkan data maka melakukan pembuatan tabel yang ada di miscrosoft excel sesuai kebutuhan, lalu setelah tabelnya selesai dibuat selanjutnya memasukkan data pegawai yang telah dikumpulkan dan mengecek apakah data tersebut sudah sesuai atau belum, jika belum lakukan pengecekan ulang pada data tetapi jika sudah benar maka langsung mengaktifkan fitur filter yang sudah tersedia di microsoft excel, setelah data yang dikumpulkan sudah dimasukkan semua dan datanya sudah sesuai maka langkah selanjutnya adalah mengimplementasi sistem yang di buat jika sudah sesuai dengan yang dinginkan maka proses selesai. 


\section{B. Analisis Sistem}

Dinas Kesehatan Kota Bima membutuhkan Sistem Informasi kepegawaian untuk memudahkan bagian kepegawaian yang berperan penting dalam pencatatan dan pelaporan data-data pegawai di lembaga Dinas Kesehatan Kota Bima, karena pencarian dan pencatatan data pegawai masih dilakukan secara manual yaitu dengan cara bagian Kepegawaian mencari data pegawai yang ada di lemari arsip sehingga memakan waktu yang cukup lama ketika mencari. Sistem Informasi kepegawaian menggunakan Microsoft Excel memanfaatkan salah satu fitur filter yag ada miscrosoft excel yang bertujuan untuk mempermudah bagian kepegawaian melakukan pencatatan dan peloran data pegawai dengan cara melakuakn filter data yang ingin dicari tanpa harus mencari data pegawai yang ada di lemari arsip.

\section{Flowchart/ diagram alir sebelum adanya sistem kepegawaian}

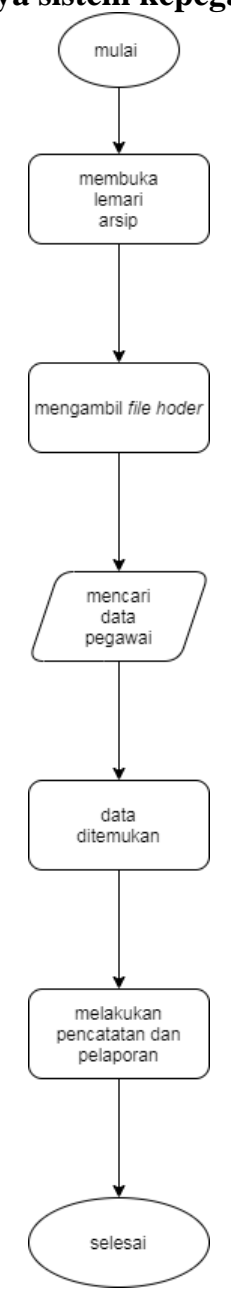

Gambar 6 Flowchart/diagram alir sebelum ada sistem kepegawaian

Gambar 6 menjelaskan mengenai flowchart /diagram alir sebelum adanya sistem kepegawaian, proses pecarian data pegawai sebelum adanya sistem kepegawaian ini dilakukan dengan cara, membuka kembali lemari arsip yang berisi data pegawai, kemudian mengambil dan memilih data pegawai yang ada di file holder yang sesuai dengan jabatan ataupun sesuai dari golongan pegawai itu sendiri, kemudian mulai mencari data pegawai dengan membuka satu persatu berkas yang sudah di cetak sehingga memakan waktu yang cukup lama, setelah datanya ditemukan baru dilakukan pencatatan dan pelaporan data.

\section{Flowchart/diagram alir setelah adanya sistem kepegawaian}




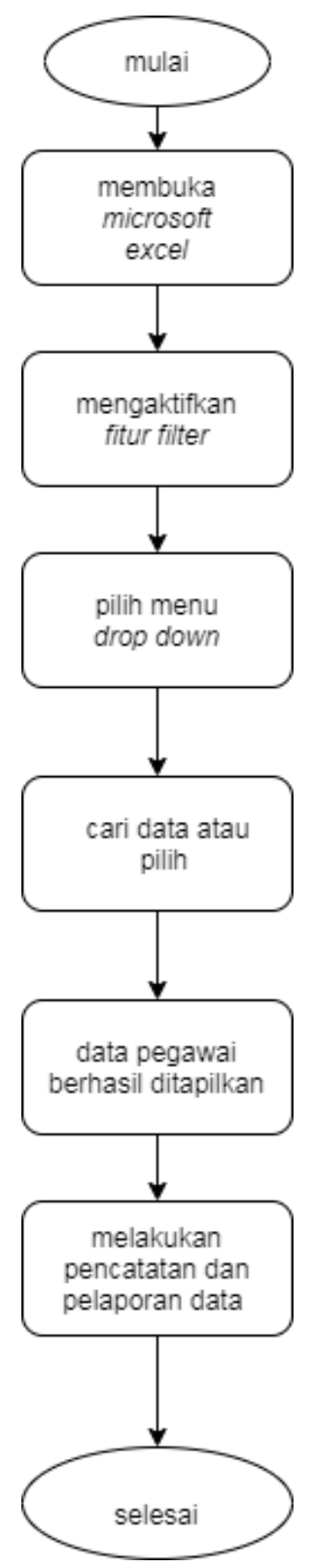

Gambar 7 Flowchart/diagram alir setelah ada sistem kepegawaian

Gambar 7 menjelaskan mengenai flowchart/diagram alir setelah sistem adanya sistem, proses pencarian data lebih muda dilakukan tanpa harus membuka lemari arsip dan membuka satu persatu berkas yang ada di file holder, cara pencarian data setelah adanya sistem yaitu membuka microsoft excel yang berisikan data pegawai, kemudian mengaktifkan fitur filter yang sudah tersedia di microsoft excel lalu klik menu drop down untuk memilih atau cari data yang ingin ditampilkan, setelah datanya berhasil dipilih maka sistem akan menampilkan data yang dicari, selanjutnya setelah data ditemukan baru dilakukan pencatatan dan pelaporan data pegawai.

\section{Analisis masalah dan kebutuhan}

Keamanan data dari sistem yang dibuat masih kurang terjamin keamanannya, karena sistem berbentuk file maka sangat rawan terserang virus ataupun jika terjadi error pada komputer bisa jadi file yang disimpan dapat hilang atau corrupted file, maka dari itu sangat dibutuhkan sistem keamanan data tambahanan yang bisa mengamankan data sistem di Dinas Kesehatan Kota Bima agar menjadi aman, solusi agar data yang disimpan rawan terserang virus yaitu menggunakan software anti virus yang berbayar agar software tersebut dapat mengamankan file dari serangan virus, sedangkan solusi jika terjadi error pada komputer dan bisa mengakibatkan corrupted file yaitu bisa menyimpan file cadangan di hardisk agar ketika komputernya error dan filenya hilang maka bisa dimbil lagi di hardisk. 


\section{KESIMPULAN}

Kesimpulan dari penelitian ini adalah sistem informasi kepegawaian Dinas Kesehatan Kota Bima masih bersifat manual sehingga sangat dibutuhkan sistem informasi yang mempermudah pekerjaan bagian kepegawaian dalam mengolah data pegawai yang lebih efektif dan efisien, sehingga dibuatlah sistem yang dapat memudahkan bagian kepegawaian dalam melukakan proses pencarian data pegawai dengan menggunakan fitur fiter di microsoft excel, kemudian diharapkan adanya upaya pengembangan lebih lanjut menjadi Sistem Informasi Keepegawaian yang lebih baik dengan penambahan fitur berbasis web yang nantinya akan semakin memudahkan proses pencarian data-data nama pegawai.

\section{REFERENSI}

[1] R. Harisca, A. Huda, and L. Slamet, "Pengembangan Sistem Informasi Kepegawaian Berbasis Web Pada Man 1 Padang,” J. Vokasional Tek. Elektron. Dan Inform., vol. 5, no. 2, pp. 148-154, 2017.

[2] W. W. Widiyanto, "Analisa Metodologi Pengembangan Sistem Dengan Perbandingan Model Perangkat Lunak Sistem Informasi Kepegawaian Menggunakan Waterfall Development Model, Model Prototype, Dan Model Rapid Application Development (Rad)," J. Inf. Politek. Indonusa Surakarta ISSN, vol. 4, no. 1, pp. 34-40, 2018.

[3] M. Tonggiroh, "Sistem Informasi Kepegawaian Pada Kantor Dewan Teknologi Informasi Dan Komunikasi Provinsi Papua Berbasis Web," Buku Mater. IT Lit., vol. 2, no. 1, pp. 1-116, 2018.

[4] N. Resources et al., "Faktor-Faktor yang Mempengaruhi Kinerja Pegawai di Kabupaten Banggai Kepulauan,” Director, vol. 15, no. 40, pp. 6-13, 2018.

[5] H. D. Lumbanraja, "Perancangan Sistem Informasi Akademik Online Menggunakan Black Box Testing Pada Sekolah Tinggi Ilmu Ekonomi Surya Nusantara,” TeIKa, vol. 8, no. 2, pp. 9-18, 2018, doi: 10.36342/teika.v8i2.664.

[6] R. Juwita, "Pengaruh Set Kesempatan Investasi Terhadap Informasi Prediktif Laba Dalam Manajemen Laba," vol. 4, no. 2, 2018.

[7] S. Petro and K. H. Swatan, "Pelatihan Microsoft Excel Sebagai Penunjang Ketrampilan Hard Skill Bagi Siswa Pada Smk Ypsei Palangka Raya,” J. Abdimas BSI J. Pengabdi. Kpd. Masy., vol. 2, no. 2, pp. 280286, 2019, doi: 10.31294/jabdimas.v2i2.6011.

[8] D. K. K. Bima, “Tentang Dinas Kesehatan,” dikes.bimakota.go.id, 2018. .

[9] S. Supriyadi, "Community of Practitioners: Solusi Alternatif Berbagi Pengetahuan antar Pustakawan," Lentera Pustaka J. Kaji. Ilmu Perpustakaan, Inf. dan Kearsipan, vol. 2, no. 2, p. 83, 2017, doi: 10.14710/lenpust.v2i2.13476.

[10] N. I. Pratiwi, "Penggunaan Media Video Call dalam Teknologi Komunikasi,” J. Ilm. Din. Sos., vol. 1, no. 2, pp. 202-224, 2017. 